\title{
Dampak Perangkat Pembelajaran Matematika Berbasis Kompetensi Profesi Terhadap Kemampuan Pemecahan Masalah Siswa Bidang Keahlian Teknologi Informasi dan Komunikasi
}

\author{
Armiati $^{1)}$, Hestu Tansil La'ia ${ }^{2)}$ \\ ${ }^{1)}$ Universitas Negeri Padang \\ ${ }^{2)}$ STKIP Nias Selatan, Sumatera Utara \\ armiati_math_unp@yahoo.co.id,
}

\begin{abstract}
This study discusses professional competency-based mathematics learning tools for vocational high school students. The purpose of this study is to produce a mathematics learning tool that refers to the field of communication and network engineering expertise, as an effort to overcome the difficulties faced by vocational school teachers in teaching mathematics. The research is a development research that refers to the development of the Plomp model with three stages, namely the preliminary research stage, the design stage and the assessment stage. In this article the results of the assessment phase will be discussed which examines the impact of devices that have been developed on students' problem solving abilities in the field of information and communication engineering. The results obtained are an increase in students' problem solving skills that can be seen in improving the ability to understand the problem, linking the problem with the concept that has been learned, setting a solution strategy, using the strategy, checking back and summarizing the results. This ability is highly needed by vocational school students, because in their work they will face many problems that require all of these abilities. Another visible impact of student activities is an increase in student learning activities as indicated by the willingness and perseverance in completing a given task.
\end{abstract}

Keywords : Learning tool, Professional competence, Problem sokving, Vocational school

This is an open access article distributed under the Creative Commons 4.0 Attribution License, which permits unrestricted use, distribution, and reproduction in any medium, provided the original work is properly cited. $\bigcirc 2020$ by author and Universitas Negeri Padang.

\section{PENDAHULUAN}

Pemerintah menyelenggarakan pendidik an kejuruan melalui Sekolah Menengah Keju ruan (SMK) dalam rangka mempersiapkan siswa memasuki dunia kerja. Namun kenyataannya, banyak lulusan Sekolah Menengah Kejuruan yang sulit untuk mendapatkan kerja, karena lulusan sekolah kejuruan dikategorikan tidak layak dan menjadi penyumbang pengangguran terbesar, yaitu $11,41 \%$ dari 7,4 juta pengang guran di Indonesia (Kompas.com, 2018, Liputan 6.com, 2017). Kondisi ini tidak bersesuaian dengan UU No. 20, Pasal 15 tahun 2003 dan Permen RI No. 17 Pasal 76 tahun 2010. Melalui Permen tersebut dinyatakan bahwa pendidikan kejuruan merupakan pendidikan menengah yang mempersiapkan peserta didik terutama untuk bekerja dalam bidang tertentu. Selanjutnya, me lalui Inpres No. 9 tahun 2016, disebutkan bahwa perlu dilakukan revitalisasi pada pendidikan kejuruan agar lulusannya mampu bersaing dalam dunia kerja.

Salah satu penyebab tidak terserapnya lulusan sekolah kejuruan di dunia kerja adalah karena rendahnya kualitas lulusan, sebagai aki bat tidak tercapainya standard kompetensi lu lusan. Salah satu komponen yang menjadi per hatian dalam standard kompetensi kelulusan adalah kemampuan siswa berfikir melalui fakta, konsep, operasi-operasi dasar, prinsip, dan ke mampuan kognitif yang lebih tinggi sesuai dengan bidang dan lingkup kerja pada tingkat teknis, spesifik, detil, dan kompleks, serta se suai dengan ilmu pengetahuan, teknologi, seni, budaya dan humaniora. Kemampuan ini meru pakan kemampuan pemecahan masalah terkait bidang keahliannya. Jika kondisi ini dibiarkan tentu akan berdampak buruk terhadap situasi Negara Indonesia dengan keaneka ragaman bu daya dan wilayahnya.

Pemecahan masalah merupakan salah satu kemampuan yang menjadi tujuan utama dalam pembelajaran matematika di sekolah kejuruan (Permendiknas, 2014). Suprijono (Siska, 2015) menyatakan bahwa belajar memecahkan masa lah merupakan kegiatan belajar yang dapat me nuntun siswa mengembangkan kemampuan ber pikir dalam aktivitas kognitif tingkat tinggi. Sementara itu, Susanto (2014) mengatakan bahwa pembelajaran matematika merupakan 
salah satu displin ilmu yang dapat melatih siswa meningkatkan kemampuan berpikir dan berargu mentasi. Lebih lanjut disebutkan dengan mate matika siswa dapat memberikan kontribusi dalam penyelesaian masalah sehari- hari dan dalam dunia kerja,serta memberikan dukungan dalam pengembangan ilmu pengetahuan dan teknologi. Artinya siswa sekolah kejuruan pela jaran matematika lebih diutamakan untuk memenuhi kebutuhan masa depan yaitu membe rikan kemampuan dasar sistematis, kritis, dan cermat dalam berpikir objektif (Armiati, 2018), sehingga mereka mampu menyelesaikan masa lah yang dihadapkan dalam pekerjaannya. Kemampuan pemecahan masalah pada dasarnya merupakan tujuan utama dari proses pendidikan, karenanya setiap guru mempunyai kewajiban untuk melatihkan kemampuan ini pada setiap siswa.

Sehubungan dengan kemampuan peme cahan masalah Bair (Căprioară, 2015) menyebut kan bahwa pemecahan masalah dapat merang sang motivasi terha dap kemajuan intelektual, kreativitas dan perilaku mental yang bertujuan menciptakan struktur yang lebih baik dari penge tahuan siswa. Pemecahan masalah mengembang kan rasa ingin tahu dan semangat meneliti serta keinginan untuk mengetahui kegunaan subjek yang diajarkan melalu pemecahan persoalan yang konkrit. Artinya kemampuan pemecahan masalah siswa juga berkaitan erat dengan motivasi dalam belajar. Senada dengan hal itu Nesher et al (Bae Seh, 2015), mengemukakan bahwa memecahkan masalah dalam matematika mengantarkan seseorang pada kemampuan untuk menyimpulkan informasi baru dari data yang tertentu. Kutipan ini menjelaskan bahwa kemampuan pemecahan masalah akan mem bantu seseorang membuat keputusan berdasar kan informasi serta gejala yang ada. Hal ini berarti kemampuan pemecahan masalah sangat diperlukan oleh lulusan sekolah kejuruan untuk dapat bersaing dalam dunia kerja. Menurut Crahay (Căprioară D, 2015) memecahkan masa lah di dunia nyata, disebut pemodelan matema tika yang dapat dipahami sebagai sebuah proses kompleks yang berisi beberapa tahapan yakni memahami situasi masalah, pembangunan mo del matematis yang menggambarkan inti dari unsur-unsur yang signifikan dan hubungan yang terlibat dalam situasi tersebut, penerapan model matematis untuk memecahkan masalah, kon tekstual, dan interpretasi dari hasil yang disedia kan oleh model diterapkan.
Pemecahan masalah merupakan salah sa tu kemampuan yang menjadi tujuan utama dalam pembelajaran matematika, sehingga ke mampuan ini harus dilatihkan guru kepada siswa dalam pembelajaran matematika. Namun Kenya taan yang ditemukan, siswa sekolah kejuruan secara umum tidak menyukai matematika, ka rena menganggap pelajaran matematika terlalu sulit dan kurang bermanfaat. Sikap siswa ter hadap pembelajaran matematika sangat dipe ngaruhi oleh cara mengajar guru. Berdasarkan observasi dan wawancara dengan beberapa guru matematika sekolah kejuruan dalam kelompok Musyawarah Guru Mata Pelajaran (MGMP) Su matera Barat (September 2017, Agustus 2018), diketahui pembelajaran di sekolah kejuruan dilaksanakan dengan cara yang sama untuk semua program keahlian yang ada, bahkan cen derung sama dengan pembelajaran matematika di sekolah menengah umum. Padahal dari karak teristik dan tujuan pendidikan sekolah umum dan sekolah kejuruan sangat berbeda. Tujuan utama dari Sekolah menengah kejuruan adalah mempersiapkan siswa agar langsung dapat beker ja setelah menyelesaikan pendidikan, sedangkan sekolah menengah umum dipersiapkan untuk melanjutkan pendidikan. Pembelajaran matema tika yang diberikan di sekolah umum lebih bersifat teoritis, sedangkan pembelajaran mate matika yang dibutuhkan siswa sekolah kejuruan adalah pembelajaran matematika yang bersifat praktis. Artinya penyajian materi matematika hendaknya menunjukkan manfaat atau kaitan dengan bidang pekerjaan yang akan digeluti sis wa setelah menyelesaikan pendidikan di sekolah kejuruan. Karena pembelajaran yang diberikan belum memperhatikan keterkaitan materi de ngan dunia nyata, mengakibatkan rendahnya ke mampuan pemecahan masalah siswa sekolah kejuruan. Sejauh ini masalah matematika yang sering terjadi dalam pendidikan adalah kurang nya kemampuan pemecahan masalah, yang mem pengaruhi hasil belajar serta aktivitas belajar siswa.

Penelitian yang terkait dengan kemam puan pemecahan masalah siswa telah banyak dilakukan. Penelitian tersebut dilakukan hampir pada setiap tingkatan sekolah. Ulu (2017), Rajotte, et al (2016), Ozsoy, et al (2015), Kaya, et al (2013, Karatas, and Baki (2013) telah mela kukan penelitian terkait peningkatan kemam puan siswa sekolah dasar dalam memecahkan masalah. Pada tingkat menengah pertama pene litian dilakukan oleh Yustianingsih (2017), Ma 
waddah (2015), dan Yuniarti (2014). Sangpong, et al (2016) melakukan penelitian terkait kemam puan pemecahan masalah di sekolah menengah umum, sedangkan Fitra (2016) melakukan pene litian di sekolah kejuruan. Ditemukan bahwa kemampuan pemecahan masalah merupakan bagian yang paling memprihatinkan dalam pem belajaran matematika. Berdasarkan kajian yang dilakukan para peneliti ini diketahui bahwa pem belajaran yang diawali dengan pemberian masa lah (PBL) dapat meningkatkan kemampuan pemecahan masalah matematis siswa.

Terkait pengembangan perangkat pem belajaran matematika di sekolah kejuruan, Murti kusuma (2015), telah mengembangkan perang kat pembelajaran matematika berbasis masalah berbantuan power point bagi siswa kelas XI sekolah kejuruan. Hasil penelitiannya, melalui perangkat yang dikembangkan interaksi siswa dalam pembelajaran meningkat, baik interaksi antara siswa dan siswa maupun interaksi siswa dan guru, melalui perangkat yang disediakan siswa terlihat lebih aktif dalam proses peme cahan masalah. Subekti (2014) mengembangkan perangkat model problem solving heuristics berprinsip pengelolaan labor tenzenia bagi sis wa sekolah kejuruan kelas $\mathrm{X}$. Hasil penelitian nya menyimpulkan bahwa terdapat perbedaaan yang signifikan antara kemampuan pemecahan masalah dan motivasi belajar siswa yang belajar dengan model yang ia kembangkan dengan pembelajaran biasa.

Beberapa penelitian terkait bahan ajar berbasis kompetensi profesi telah dilakukan oleh Armiati, Makhashova, dan Omarov. Penelitian yang dilakukan oleh Makhashova (2016) dan Omarov (2016) menyebutkan bahwa perkem bangan kompetensi peserta didik dipengaruhi oleh perangkat pembelajaran yang disesuaikan dengan profesi di bidang keahlian siswa. Artinya perangkat pembelajaran yang memperhatikan profesi bidang keahlian memberikan dampak positif terhadap siswa sekolah kejuruan. Armiati dkk. $(2007,2008)$ telah mengembangkan modul matematika berbasis kompetensi profesi bagi siswa sekolah kejuruan teknologi, dari penelitian tersebut disimpulkan bahwa kemampuan peme cahan masalah, kemampuan komunikasi, minat serta motivasi siswa meningkat setelah belajar menggunakan modul matematika yang mengait kan materi matematika dengan profesi siswa. Namun, dengan berlakunya kurikulum 2013, pembelajaran di sekolah kejuruan tidak lagi menggunakan modul sehingga perlu dikembang kan bahan ajar yang sesuai dengan tuntutan kurikulum tersebut.

Kendala yang dihadapi guru matematika dalam pembelajaran matematika di sekolah keju ruan dalam mengimplementasikan kurikulum 2013 adalah kurangnya bahan ajar yang sesuai dengan program keahlian siswa. Selain itu guru juga mengalami kesulitan mengatur waktu untuk dapat merancang perangkat pembelajaran yang sesuai untuk setiap bidang keahlian. Kewajiban mengajar 24 jam setiap minggu membuat guru mengalami kesulitan dalam merancang persiap an mengajar yang sesuai. Untuk mengatasi hal tersebut telah dilakukan penelitian pengem bangan untuk mendapatkan perangkat pembela jaran rencana pembelajaran dan lembar kerja siswa yang diperkirakan mampu memfasilitasi guru dan siswa dalam membahas materi pela jaran matematika. Perangkat ini disebut dengan perangkat pembelajaran matematika berbasis kompetensi profesi, karena dalam penyampaian materi matematika digunakan masalah-masalah yang terkait kompetensi profesi siswa di sekolah kejuruan. Ciri utama dari pembelajaran berbasis kompetensi profesi adalah permasalahan awal untuk suatu materi matematika selalu dikaitkan dengan permasalahan dalam bidang keahlian siswa. Selanjutnya, masalah tersebut diarahkan penyelesaiannya menggunakan konsep matema tika. Untuk memahami matematika secara kon septual, siswa juga diberikan latihan dalam ben tuk soal yang tidak memuat masalah keahlian nya, hal ini dilakukan agar siswa tetap mampu menyelesaikan soal matematis dari segi teoritis. Pada bagian akhir siswa kembali diberikan masa lah terkait bidang keahlian dan soal perhitungan matematika (Armiati, 2018).

Melalui penelitian ini telah dikembangkan perangkat pembelajaran matematika berbasis kompetensi profesi untuk bidang keahlian teknik informatika dan komunikasi. Tujuan dari pene litian ini adalah mendapatkan perangkat pem belajaran matematika berupa rencana pembela jaran bagi guru dan lembar kerja bagi siswa yang dapat mengatasi kesulitan guru matematika dan siswa. Perangkat ini diharapkan memberi kan kontribusi terhadap perbaikan kualitas pendi dikan di sekolah kejuruan, terutama dalam upa ya meningkatkan kemampuan pemecahan masa lah matematis siswa sekolah kejuruan. Bila pada penelitian-penelitian sebelumnya, pembelajaran berbasis masalah digunakan untuk meningkat kan kemampuan pemecahan masalah siswa, maka dalam penelitian ini permasalahan yang 
diajukan disesuaikan dengan kompetensi siswa sekolah kejuruan. Pada penelitian ini permasa lahan dikaitkan dengan bidang keahlian teknik informatika dan komunikasi dan mengacu pada profesi yang akan dijalani setelah menyelesaikan pendidikan di sekolah kejuruan. Artikel ini mem bahas sebagian dari hasil yang telah diperoleh dalam penelitian, yaitu ingin mengetahui "Bagai manakah dampak perangkat pembelajaran berba sis kompetensi profesi terhadap kemampuan pemecahan masalah matematis siswa bidang keahlian teknik informatika dan komunikasi?"

\section{METODE PENELITIAN}

Penelitian ini yang mengacu pada peneli tian pengembangan model Plomp (Plomp, T \& Nievenn N. 2013), yang tiga tahapan dalam penelitian ini, yaitu tahap preliminary research, tahap design, dan tahap assessment. Pengkajian tentang dampak merupakan bagian dari tahap disain, yaitu pada bagian evaluasi formatif. Evaluasi formatif dilakukan setelah didapatkan prototype awal dari perangkat yang dirancang dan perangkat dinyatakan valid dan layak digunakan berdasarkan pendapat para pakar, dalam hal ini pakar matematika dan pendidikan matematika. Tahap evaluasi formatif meliputi beberapa kegiatan, yaitu evaluasi sendiri, evalua si satu-satu, kelompok kecil dan uji lapangan. Pengujian tentang dampak dilakukan pada ke giatan kelompok kecil dan uji lapangan pada kelompok terbatas. Pada kegiatan kelompok kecil dilibatkan 6 orang siswa dengan kemam puan berbeda, yaitu siswa dengan kemampuan tinggi, sedang dan rendah. Uji lapangan dilaku kan dengan melibatkan dua kelas sebagai kelas uji coba, satu sebagai kelas eksperimen dan satu sebagai kelas control. Metode yang digunakan pada uji lapangan adalah metoda quasi ekspe rimen dengan rancangan post test only design. Untuk keperluan uji coba ini digunakan dua kelas sebagai sampel. Secara ringkas langkahlangkah evaluasi disajikan pada Gambar 1 yang disadur dari Plomp and Nieveen (2013).

Subjek uji coba dalam penelitian pengem bangan ini adalah siswa kelas X SMK Negeri 1 Sintuk Toboh Gadang pada bidang keahlian Teknologi Informasi dan Komunikasi yang ter diri dari dua program keahlian yakni Teknik Komputer dan Jaringan (TKJ) dan Rekayasa Perangkat Lunak (RPL). Penetapan sampel dimu lai dengan memilih dua kelas yang memiliki karakteristik sama pada bidang keahlian teknik informasi dan komunikasi.

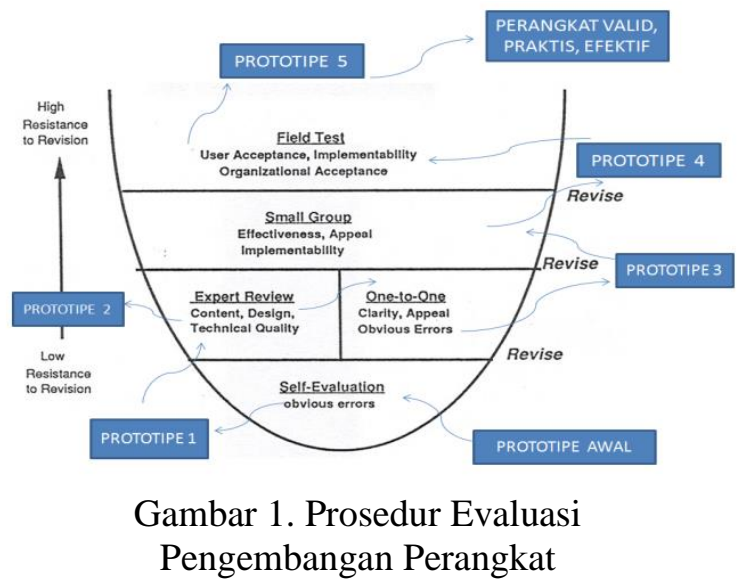

Sebagai sampel pada penelitian ini ada lah siswa kelas X TKJ-1 sebagai kelompok eks perimen sedangkan kelompok kontrol adalah kelas X RPL-2. Pembelajaran pada kelas ekspe rimen dilakukan dengan menggunakan perang kat yang telah dirancang, dan telah dinyatakan valid serta layak pakai oleh pakar. Sedangkan di kelas kontrol pembelajaran dilakukan dengan pembelajaran konvensional yaitu pembelajaran yang telah digunakankan oleh guru matematika sekolah kejuruan tempat uji coba.

Dampak produk yang dikembangkan akan diketahui melalui praktikalitas dan efektivitas produk. Untuk mengetahui praktikalitas diberi kan angket kepada siswa dan guru yang terlibat dalam penelitian ini. Praktikalitas perangkat ditinjau dari kemudahan penggunaan dan dari kesesuaian waktu yang direncanakan dengan pelaksanaan. Untuk mengetahui dampak terha dap kemam puan pemecahan masalah diberikan tes kemampuan pemecahan masalah setelah pelaksanaan pembelajaran menggunakan perang kat. Sebelum digunakan, instrumen penelitian diuji validitas yaitu validitas isi dan telah diuji cobakan untuk mengetahui reliabelitasnya, daya beda serta tingkat kesukaran tes.

Analisis data dilakukan secara deskriptif, yaitu mendeskripsikan hasil angket siswa untuk selanjutnya dikategorikan. Analisis data diawali dengan analisis frekuensi dengan menggunakan rumus yang dikemukakan oleh Purwanto (2004) sebagai berikut.

$$
\mathrm{P}=\frac{\mathrm{R}}{\mathrm{SM}} \times 100 \%
$$

Keterangan:

P : Nilai Kepraktisan 
R : Skor yang Diperoleh

SM : Skor Maksimum

Selanjutnya, digunakan kategori kepraktisan dengan klasifikasi seperti pada Tabel 1 berikut.

Tabel 1. Kriteria Kepraktisan

\begin{tabular}{|c|c|}
\hline $\begin{array}{c}\text { Nilai Kepraktisan } \\
(\%)\end{array}$ & Kriteria \\
\hline $85 \leq \mathrm{P} \leq 100$ & Sangat Praktis \\
\hline $75 \leq \mathrm{P}<85$ & Praktis \\
\hline $60 \leq \mathrm{P}<75$ & Cukup Praktis \\
\hline $55 \leq \mathrm{P}<60$ & Kurang Praktis \\
\hline $0 \leq \mathrm{P}<55$ & Tidak Praktis \\
\hline Sumber: Purwanto (2009:103)
\end{tabular}

Data pada tahap small group dianalisis dengan analisis deskriptif, yaitu dengan mendes kripsikan capaian siswa berdasarkan indikator pemecahan masalah. Selanjutnya, dibandingkan dengan kriteria ketuntasan minimal seperti pada Tabel 2.

Tabel 2. Kualifikasi Kemampuan Pemecahan Masalah Matematis Siswa

\begin{tabular}{|c|c|}
\hline Rentang Nilai & Kualifikasi \\
\hline $85-100$ & Sangat Baik \\
\hline $70,00-84,99$ & Baik \\
\hline $55,00-69,99$ & Cukup \\
\hline $40,00-54,99$ & Kurang \\
\hline $0-39,99$ & Sangat Kurang \\
\hline
\end{tabular}

Selanjutnya dilakukan uji lapangan yang bertujuan untuk mengetahui efektivitas dari perangkat. Perangkat dikatakan efektif apabila hasil tes kemampuan pemecahan masalah mate matis siswa pada kelas eksperimen berada pada kategori baik, yaitu $\geq 70 \%$. Hal ini berarti, ratarata hasil pemecahan masalah berada di atas KKM. Untuk menentukan persentase peserta didik yang tuntas digunakan rumus berikut.

$$
\mathrm{p}=\frac{\text { Jumlah peserta didik yang tuntas }}{\text { jumlah seluruh peserta didik }} \times 100 \%
$$

Penentuan $70 \%$ berdasarkan interval ketuntasan belajar yang dikemukakan oleh Arikunto seperti pada Tabel 3.

Pada tahap uji lapangan, selain mengkate gorikan, efektifvtas perangkat dilihat dengan membandingkan kemampuan pemecahan masa lah siswa yang belajar menggunakan perangkat pembelajaran berbasis kompetensi profesi de ngan kemampuan pemecahan masalah siswa yang belajar tanpa perangkat berbasis kompeten si profesi. Analisis data untuk uji ini adalah uji t. Hipotesis yang diuji untuk mengetahui efektivi tas ini adalah "Apakah kemampuan pemecahan masalah siswa yang belajar dengan perangkat pembelajaran matematika berbasis kompetensi profesi lebih baik dari kemampuan pemecahan masalah siswa yang belajar tanpa perangkat pembelajaran berbasis kompetensi profesi?"

Tabel 3.Interval Ketuntasan Belajar

\begin{tabular}{|c|c|c|}
\hline No & Interval & Kategori \\
\hline 1 & $0 \%-39 \%$ & Sangat Kurang \\
\hline 2 & $40 \%-55 \%$ & Kurang \\
\hline 3 & $56 \%-65 \%$ & Cukup \\
\hline 4 & $66 \%-79 \%$ & Baik \\
\hline 5 & $80 \%-100 \%$ & Sangat Baik \\
\hline
\end{tabular}

Untuk keperluan ini data dianalisis mengguna kan software SPSS.

\section{HASIL DAN PEMBAHASAN}

Small group diikuti oleh 6 orang siswa yang terdiri dari 2 orang siswa dengan kemam puan matematika tinggi, 2 orang siswa dengan kemampuan matematika sedang, dan 2 orang siswa dengan kemampuan matematika rendah. Selanjutnya mereka dibagi dalam dua kelompok beranggotakan tiga orang dengan anggota kelom pok yang heterogen. Pada kegiatan small group kegiatan pembelajaran dilaksanakan oleh salah seorang anggota tim peneliti sebanyak 8 kali pertemuan. Uji lapangan juga dilakukan seba nyak 8 kali pertemuan untuk materi yang sama, kegiatan pembelajaran dilakukan oleh salah seo rang guru matematika di sekolah kejuruan SMK N 1 Sintuk Toboh Gadang Pariaman Sumataera Barat. Saat uji lapangan tim peneliti bertindak sebagai observer. Materi yang diujikan saat small group dan uji lapangan adalah materi untuk KD 3.11 yaitu Menerapkan aturan sinus dan kosinus dan untuk KD 4.11 Menyelesaikan permasalah kontekstual dengan aturan sinus dan kosinus.

\section{Hasil pada tahap small group}

Kegiatan pada tahap small group dilaku kan oleh salah seorang anggota tim peneliti dan salah seorang guru yang akan melaksanakan pembelajaran pada tahap uji lapangan yang dili batkan sebagai observer. Pada pertemuan awal siswa masih memerlukan banyak bantuan dari peneliti dalam memahami masalah, terutama sis wa dengan kemampuan sedang dan rendah. Sete lah empat pertemuan siswa mulai bisa meman faatkan kerja kelompok dalam mempelajari ma 
teri. Dalam hal ini, siswa masih tetap diberi pendampingan. Pada tahap small group, kendala yang dihadapi siswa adalah rendahnya kemam puan prasayarat yang dibutuhkan siswa untuk mampu menyerap materi yang diberikan dalam bahan ajar. Kondisi ini terjadi karena biasanya dalam pembelajaran siswa hanya diberikan ru mus, kemudian menghafal rumus tersebut untuk digunakan dalam menyelesaikan soal. Mengatasi hal tersebut diberikan arahan pada permasalahan yang disajikan terkait bidang keahliannya. Pada pertemuan ke-enam, terlihat bahwa kemampuan matematis siswa sudah mulai baik, mereka su dah mampu memahami masalah dan membuat penyelesaiannya, kemampuan tersebut semakin baik sampai pada pertemuan ke-delapan.

Selama pelaksanaan small group, siswa diwawancarai setiap kali mereka menemukan ke sulitan dalam mengerjakan Lembar Kerja Peser ta Didik (LKPD). Berdasarkan kesulitan yang dihadapi siswa dilakukan perbaikani perangkat yang telah dirancang. Secara umum, siswa kesu litan dalam mengaitkan masalah yang diberikan di awal dengan pengetahuan matematika mere ka. Untuk mengatasi hal ini dilakukan revisi pa da perangkat dengan menambahkan beberapa ta hapan yang dapat dipedomani siswa dalam men jawab soal. Pada akhir pertemuan ke-delapan, siswa diberikan angket. Hal ini berguna untuk mengetahui tanggapan siswa terhadap perangkat yang digunakan guna mengetahui praktikalitas perangkat. Aspek yang dinilai oleh siswa mela lui angket adalah aspek penyajian, aspek kemu dahan penggunaan, alokasi waktu dan keterba caan. Untuk aspek penyajian, aspek kemudahan dan aspek alokasi waktu, perangkat tergolong sangat praktis, persentase masing-masing adalah $86,11 \%$; $85,42 \%$; dan $87,50 \%$ sedangkan un tuk keterbacaan tergolong praktis dengan per sentase $83,3 \%$. Secara keseluruhan pada tahap small group hasil angket kepraktisan menunjuk kan perangkat sangat praktis dengan persentase kepraktisan $85,59 \%$. Selanjutnya, untuk perte muan berikutnya dilakukan tes kemampuan pe mecahan masalah untuk mengetahui dampak perangkat terhadap kemampuan pemecahan ma salah siswa sekolah kejuruan. Hasil tes diberikan pada Tabel 4.

Pada Tabel 4, terlihat bahwa persentase ketuntasan belajar siswa pada small group adalah $83,33 \%$, hasil ini berada pada kategori baik. Artinya bahwa pembelajaran dengan meng gunakan perangkat pembelajaran berbasis kom petensi profesi efektif digunakan untuk mengem bangkan kemampuan pemecahan masalah siswa sekolah kejuruan kelas X bidang keahlian tekno logi informasi dan komunikasi. Perangkat yang telah direvisi setelah tahap small group dinama kan prototype IV.

Tabel 4. Hasil Tes Kemampuan Pemecahan Masalah pada Small Group Evaluation

\begin{tabular}{|c|c|c|c|}
\hline $\begin{array}{c}\text { Inisial } \\
\text { Peserta } \\
\text { Didik }\end{array}$ & KKM & $\begin{array}{c}\text { Hasil } \\
\text { Tes }\end{array}$ & Keterangan \\
\hline AA (T1) & 70 & 90,91 & Tuntas \\
\hline BG (T2) & 70 & 83,64 & Tuntas \\
\hline MI (S1) & 70 & 85,45 & Tuntas \\
\hline WP (S2) & 70 & 81,82 & Tuntas \\
\hline MW (R1) & 70 & 52,73 & Tidak Tuntas \\
\hline SH (R2) & 70 & 76,36 & Tuntas \\
\hline \multicolumn{2}{|c|}{$\begin{array}{c}\text { Persentase } \\
\text { Ketuntasan }\end{array}$} & $\mathbf{8 3 , 3 3 \%}$ \\
\hline
\end{tabular}

Selanjutnya, perangkat diuji lagi pada tahap field test.

\section{Hasil pada tahap field test.}

Hal yang diamati selama uji lapangan ada lah praktikalitas dan efektivitas perangkat yang dikembangkan. Praktikalitas dicermati melalui pemberian angket kepada siswa dan juga kepada guru di akhir pertemuan ke delapan. Kemudian kepada siswa diberikan tes kemampuan peme cahan masalah untuk mengetahui efektifvtas pe rangkat. Tes ini diberikan kepada siswa dalam kelompok eksperimen siswa kelompok kontrol.

Berdasarkan hasil angket yang diberikan kepada siswa saat field test, untuk aspek penya jian, aspek kemudahan dan aspek alokasi waktu perangkat tergolong sangat praktis, dengan per sentase masing-masingnya $88,02 \%, 87,37 \%$, dan $87,11 \%$ sedangkan untuk keterbacaan tergolong praktis dengan persentase $83,69 \%$. Secara keselu ruhan pada tahap field test hasil angket keprak tisan menunjukkan perangkat terkategori sangat praktis dengan persentase kepraktisan 86,52\%, dengan kategori sangat praktis. Hasil praktikali tas perangkat berdasarkan angket yang diisi oleh guru adalah $86,16 \%$ tergolong sangat praktis, dengan rincian aspek daya tarik $89,84 \%$, aspek kemudahan penggunaan $81,15 \%$, aspek waktu $87,50 \%$. Dengan demikian, dapat dikatakan bah wa perangkat sudah praktis menurut pengguna yaitu guru matematika dan siswa pada sekolah kejuruan.

Setelah dilakukan analisis terhadap tes kemampuan pemecahan masalah, dari 30 siswa kelas X TKJ-1, terdapat 4 orang yang tidak tun 
tas. Rata-rata hasil tes kemampuan pemecahan masalah sebesar 78,61, hasil ini lebih besar da ri Kriteria Ketuntasan Minimun (KKM) 70 dan persentase ketuntasan $86,67 \%>70 \%$. Berdasar kan kriteria ketuntasan belajar, hasil ini berada pada kategori sangat baik, ini berarti bahwa pe rangkat pembelajaran berbasis kompetensi pro fesi yang dirancang telah memberikan dampak yang positif terhadap kemampuan pemecahan masalah siswa sekolah kejuruan.

Selanjutnya dilakukan pengujian dengan membandingkan hasil yang diperoleh kelas eks perimen dengan capaian kelas kontrol. Hasil yang dibandingkan adalah selisih kemampuan awal dan kemampuan akhir dari kedua kelom pok sampel. Kemampuan awal kelas eksperi men adalah 66,6 sedangkan kelompok kontrol adalah 67,5. Hasil akhir untuk kelompok ekspe rimen 78,61 dan kelompok kontrol 75,2. Dari angka ini terlihat bahwa hasil yang diperoleh kelompok eksperimen lebih tinggi dari hasil yang diperoleh kelompok kontrol.

\section{KESIMPULAN}

Kesimpulan yang dapat diambil melalui penelitian ini adalah perangkat tergolong sangat praktis baik dari siswa maupun guru yang meng gunakan produk ini. Aspek yang dilihat adalah aspek penyajian, aspek kemudahan penggunaan, alokasi waktu dan keterbacaan. Perangkat juga berdampak terhadap kemampuan pemecahan ma salah siswa. Berdasarkan tes yang dilakukan saat small group maupun field test rata-rata kemam puan pemecahan masalah siswa lebih tinggi dari ketuntasan minimal. Kondisi ini disebabkan pa da perangkat pembelajaran berbasis kompetensi profesi, siswa dihadapkan pada masalah-masa lah yang berkaitan langsung dengan bidang keah liannya. Sehingga pembelajaran matematika menjadi lebih bermakna, dan siswa merasakan manfaat matematika pada bidang kehaliannya. Hal ini berarti perangkat yang dirancang membe rikan dampak yang baik terhadap kemampuan pemecahan masalah siswa dan juga sikap siswa terhadap pembelajaran matematika.

Untuk itu, dapat disarankan kepada guru sekolah kejuruan agar dalam mengajarkan mate matika dapat mengaitkan permasalahan matema tika dengan bidang keahlian siswa. Sebagai alter natif guru matematika sekolah kejuruan dapat menggunakan perangkat yang sudah dirancang ini dalam mengajar matematika pada bidang keahlian teknik informasi dan komunikasi.

\section{DAFTAR PUSTAKA}

Arikunto, S. (2012). Dasar-Dasar Evaluasi Pen didikan. Jakarta: Bumi Aksara

Armiati (2018). Mengembangkan Higher Order Of Thinking Skill Siswa Sekolah Mene ngah Kejuruan Melalui Pembelajaran Matematika Berbasis Kompetensi Pro fesi. SEMNAS MAT STKIP SUMBAR

Bae Seh Y. et al. (2015). Mathematical Word Problem Solving Ability of Children with Autism Spectrum Disorder and Their Typically Developing Peers. Jour nal. J Autism Dev Disord DOI 10.1007/ s10803-015-2387-8.

Căprioară D. (2015). Problem Solving - Purpose And Means Of Learning Mathematics In School. Journal. Social and Behavioral Sciences 191 (2015) 1859 - 1864.

Fitra, R. dkk. (2016). Peningkatan Kemampuan Pemecahan Masalah Siswa SMK Mela lui Model Problem Based Instruction (PBI). Jurnal Didaktik Matematika. ISSN: 2355-5185. Vol 3, No. 2, Septem ber 2016.

Gonzalez, P. (2016). Improvement of Word Problem Solving and Basic Mathema tics Competencies in Students with Attention Deficit/ Hyperactivity Disor der and Mathematical Learning Difficul ties. Learning Disabilities Research \& Practice, OO(0), 1-14. DOI: 10.1111/ ldrp.12106.

Karatas, I., \& Baki, A. (2013). The Effect of Learning Environments Based on Prob lem Solving on Students' Achievements of Problem Solving. International Elec tronic Journal of Elementary Education, 2013, 5(3), 249-268.

Kaya, D. dkk. (2013). The Investigation of Elementary Mathematics Teacher Candi dates' Problem Solving Skills Accor ding to Various Variables. International Electronic Journal of Elementary Educa tion, 2014, 6(2), 295-314.

Kompas. com. (2018). Alasan Lulusan SMK Banyak Menganggur. Diakses dari: https://edukasi.compas.com/read/2018/0 $\underline{4 / 26 / 15342831}$

Liputan6.com. (2017). Lulusan SMK Jadi Pengangguran Paling Banyak di RI. Jakarta. Diakses dari: https://www.liputan6.com/bisnis/read/3 $\underline{153245}$ 
Maawaddah, S., \& Hana, A. (2015). Kemam puan Pemecahan Masalah Matematis Siswa pada Pembelajaran Matematika dengan Menggunakan Model Pembela jaran Generatif (Generatif Learning) di SMP. EDUMAT Jurnal Pendidikan Ma tematika, Vol. 3, No. 2.

Makhashova, P. (2016). On the Development of Professional Competence in Students of Creative Pedagogical Specialties. Inter national Journal of Environmental \& Science Education. 2016, vol. 11, No. 11, 4660-4668.

Masdalipa, dkk. (2017). The Effect of ProblemBased Learning Assisted Concept Map to Problem-Solving Ability and Critical Thinking Ability". Journal of Education and Practice. ISSN 2222-1735 (Paper) ISSN 2222-288X. Vol.8, No.19, 2017

Murtikusuma, R. P. (2015). Pengembangan Perangkat Pembelajaran Matematika Model Problem Based Learning Berban tuan Media Powerpoint Untuk Siswa Kelas XI SMK Materi Barisan dan Deret. Saintifika; Jurusan PMIPA, FKIP, Universitas Jember. P-ISSN: 1411 -5433. E-ISSN: 2502-2768.

Omarov, Y. B. dkk. (2016). Methods Of Forming Professional Competence Of Students As Future Teachers. Inter national Journal of Environmental \& Science Education. 2016, VOL. 11, NO. 1 4, 6651 -6662.

Özsoy, G dkk. (2015). Evaluation of Student's Mathematical Problem Solving Skill in Relation to Their Reading Levels. International Electronic Journal of Ele mentary Education. Vol. 8, No. 1. Hal 581-600. 2015.

Plomp, T \& Nieven N. (2013). Educational Design Research-Part A: An Introduc tion Enschede: Netherland Institute for Curriculum Development (SLO) PQ4R Strategy Accompanied by Refutation Text reading

Purwanto, N. (2009). Prinsip-prinsip dan Teknik Evaluasi Pengajaran. Bandung: Remaja Rosdakarya.

Rajotte, T. dkk. (2016). Evaluation of the Effect of Mathematical Routines on the Deve lopment of Skills in Mathematical Prob lem Solving and School Motivation of Primary School Students in AbilitiTémiscamingue. Universal Journal of
Educational Research 4(10): 23862391, 2016. DOI: 10.13189/ujer.2016. 041017.

Raharjanti, M. (2011). Pengembangan Perang kat Pembelajaran Operasi Matriks Bero rientasi Pendekatan Pemecahan Masa lah di SMK Program Keahlian Tata Niaga Kelas XII. Fakultas Keguruan Dan Ilmu Pendidikan Universitas Jember.

Rahmadhani, S. (2012). Pembelajaran Matema tika dengan Pendekatan Problem Posing untuk Meningkatkan Kemam puan Pemecahan Masalah dan Koneksi Matematis Siswa. Bandung: UPI. Dikutip dari Repository. UPI.Edu.

Rahmawati, E. dkk. (2013). Pengembangan Perangkat Pembelajaran Matematika Bilingual Melalui Model Pembelajaran Berbasis Masalah (Problem Based Instruction) Pada Sub Pokok Bahasan Persegi Panjang dan Persegi kelas VII. Kadikma, Vol. 4, No. 3, hal 81-90, Desember 2013.

Sangpom, W. et al. (2016). Advanced Mathe matical Thinking and Students' Mathe matical Learning: Reflection from Stu dents' Problem-Solving in Mathema tics Classroom. Journal of Education and Learning; Vol. 5, No. 3; 2016 ISSN 1927-5250 E-ISSN 1927-5269.

Published by Canadian Center of Science and Education.

Siska R M. (2015). Pengaruh Penggunaan Metode Student Facilitator And Ex plaining Dalam Pembelajaran Koope ratif Terhadap Kemampuan Peme cahan Masalah Matematik Siswa SMK di Kota Tasikmalaya. Jurnal Penelitian Pendi dikan dan Pengajaran Matema tika. Vol. 1 no. 1

Subekti, FE. (2014). Pengembangan Perangkat Pembelajaran Matematika Kelas X SMK dengan Model Problem Solving Heuristic Berprinsip Pengelolaan Labo ratorium Teenzania. Jurnal Euclid, ISSN 2355-1712, vol.1, No.2, pp. 60136. 2014.

Ulu, M. (2017). The Effect of Reading Compre hension and Problem Solving Strategies on Classifying Elementary 4th Grade Students with High and Low Problem Solving Success. Journal of Education and Training Studies. Vol. 5, No. 6; 
June 201 7. ISSN 2324-805X E-ISSN 2324-8068. Published by Redfame Publishing.

Yuniarti, T. (2014). Pengembangan Perangkat Pembelajaran Berbasis Masalah (Prob lem Based Learning) Dengan Pende katan Ilmiah (ScientificApproach) Pada Materi Segitiga Kelas VII SMP SeKabupaten KaranganyarTahun Pelajaran 2013/2014. Jurnal Elektronik Pembela jaran Matematika.Vol.2, No.9, hal 911921, November 2014. ISSN: 2339-1685. Yustianingsih, R. (2017). Pengembangan Perang kat Pembelajaran Matematika Berbasis Problem Based Learning (PBL) Untuk Meningkatkan Kemam puan Pemecahan Masalah Peserta Didik Kelas VIII. Jurnal; JNPM (Jurnal Nasional Pendi dikan Matematika). September 2017 Vol. 1, No. 2, Hal. 25 